\title{
Comparison of consumer attitudes between Cyprus and Latvia: an evaluation of effect of setting on consumer preferences in the water industry
}

\author{
Jonathan Chenoweth ${ }^{1}$, Julie Barnett ${ }^{2}$, Tereza Capelos ${ }^{3}$, Chris Fife-Schaw ${ }^{4}$, Tanika Kelay ${ }^{2}$.
}

Models approaching consumer expectations of their water supplier from a risk perspective suggest that consumers primarily and overwhelmingly want safe drinking water supply. In this study consumer preferences in the water sector are investigated in two contrasting case studies: Cyprus, where there have been significant quantity and continuity of supply issues, and Riga, where there have been water quality issues. While water quality is undoubtedly the main priority of water consumers in Riga, in Cyprus consumers indicate that they prioritise a more reliable service even though many are sufficiently dissatisfied with water quality that they do not drink the tap water. The analysis of consumer attitudes in the two case studies suggests that when water supply is unreliable, reliability takes precedence; once it is reliable quality issues come to the fore.

\section{Introduction}

Water has a number of features which make it unique amongst consumer products and services. Firstly, safe water supplies are a prerequisite for stable healthy societies. Secondly, unlike most services, most consumers have no choice over their tap water supplier. There are no traditional water markets of competing suppliers in most of the world and thus consumers cannot choose a different supplier if they become dissatisfied with the water services they receive, although there is a market for bottled water, so consumers do have some choice when it comes to drinking water.

This paper examines the priorities and expectations that people have from water utilities in terms of the drinking water services they supply and relates these to theoretical models of consumer preferences for risk with water service providers. Following a theoretical review we then report on two case studies where interviews and focus groups were conducted with water industry stakeholders and water consumers respectively and where the nature of the water supply and problems facing the water industry differ significantly. The first case study investigates consumer preferences in a water supply system facing quantitative water resource stress (Nicosia, Cyprus), while the second case study considers consumer preferences in a system undergoing change and qualitative stress (Riga, Latvia). These contrasting case studies were chosen as they allow the effect of

\footnotetext{
${ }^{1}$ Centre for Environmental Strategy, University of Surrey, Guildford, Surrey, GU2 7XH, UK.

${ }^{2}$ Dept of Information Systems and Computing, Brunel University, Kingston Lane, Uxbridge, UB8 3PH, UK.

${ }^{3}$ Department of Political, International and Policy Studies, University of Surrey, Guildford, Surrey, GU2 7XH, UK.

${ }^{4}$ Department of Psychology, University of Surrey, Guildford, Surrey, GU2 7XH, UK.
} 
very different settings on consumer preferences to be evaluated. They are also interesting from a theoretical perspective as the consumer preference models for the water industry were developed primarily with reference to highly developed high income countries, but whereas Cyprus is classified as a high-income country by the World Bank, Latvia is classified as an upper-middle-income country (World Bank 2010). The paper concludes by discussing variations in consumer preferences for water supply and how these are influenced by the socio-economic setting.

\section{Consumer expectations and priorities for the water industry}

A 2004 survey of European consumer responses to a range of public services shows that satisfaction with water supplies is high compared to other services, with consumer satisfaction about water services being higher overall than with any other service evaluated except postal services (Eurobarometer 2005). Levels of satisfaction with water services were highest in Belgium where $86 \%$ of consumers were satisfied and lowest in Italy where only $65 \%$ were satisfied. Overall, $93 \%$ of consumers across Europe thought the quality of their water supply services were good, however, in Hungary and the former-Soviet Baltic states, $12 \%$ to $14 \%$ of consumers said the quality of their water supply services were "bad" or "very bad" (Eurobarometer 2005).

While the overall level of satisfaction with water services is generally high across Europe, in other regions the situation can be dramatically different. A survey conducted in the Gaza Strip, for example, found that more than 71 percent of respondents were dissatisfied with the quality of their water, 67 percent were dissatisfied with the quantity they received and 60 percent were dissatisfied with the continuity of their water supply (Al-Ghuraiza \& Enshassib 2006). However, such a high level of dissatisfaction could be expected in a region experiencing significant water quality problems and frequent supply interruptions, and is similar to results from elsewhere. In Malaysia, for example, following drought, residents affected by water supply problems were as a whole very unsatisfied with the quantity and quality of water they received and only moderately satisfied with the water crisis management strategy that was carried out (Aini et al. 2001).

As previously noted in the literature by Bates (2000), the primary expectation that consumers have of their supplier is that they provide safe drinking water. This has been confirmed by a number of studies. For example Burn et al (2003) found the two major priorities of water consumers in Australia were quality of water supply and continuity of water supply. In the UK focus groups conducted by the Consumer Council for Water (2005) found that consumers believe that the supply of clean water was the most important responsibility of water companies, with reliability of service and value for money also being key responsibilities. The UK's Drinking Water Inspectorate (1998) found that consumers prioritise safe drinking water ahead of reliability of supply.

As noted by Hrudey et al. (2006), safe does not mean the absence of any risk since to demand an absolute standard would mean that no water would ever meet this standard and thus no water could ever be considered safe. While it is clear from the literature that 
consumers want water supplies that are 100 percent safe, what is less clear is what proportion of the population expect some uncertainty and thus accept less than 100 percent safety. It is not clear what levels of risk are acceptable to different types of consumers. In formal risk assessments risk is generally defined as the probability of the occurrence of an undesirable event together with the consequences of that event (European Commission Health and Consumer Protection Directorate General 2000; Tuhovčák \& Ručka 2007; World Health Organization 2006). However, expert risk assessment does not seem to correspond with lay assessments of risk.

While a number of studies (for example, Eurobarometer (2005), Drinking Water Inspectorate (2000) Martijn et al (1998)) have shown that consumers in developed countries are generally satisfied with the quality of the water they receive, concerns about water quality in well managed water systems stem from immediate sensory perceptions consumers have of the water supplied. Where consumers notice a change in the taste of their water supply they can suspect that it is unsafe to drink (McGuire 1995). Residual levels of chlorine in water, in particular, have been correlated with decreased consumer satisfaction with water quality and increased perceptions of risk (Turgeon et al. 2004). This is despite the fact that health risks associated with drinking water may be inversely proportional to the residual level of chlorine in tap water.

Studies have shown that untrained members of the public prefer bottled water over distilled water or tap water, with water higher in mineral content being preferred (Falahee \& MacRae 1995). Many studies (for example, Department for Environment Food and Rural Affairs (2002), Institut Français de l'Environnement (2000), Means et al (2002), Drinking Water Inspectorate (2000)) find that consumption of bottled water is more a reflection of aesthetic preferences (such as taste or colour) rather than risk aversion behaviour.

Speers et al (2002) conducted a study in Australia examining consumer preferences relating to supply interruptions. While consumers surveyed could cope with short supply interruptions, the factors which were thought to be most important with supply interruptions were the duration of the interruption, whether they received advanced notification, time of day of the interruption, and number of interruptions per year (Speers et al. 2002). Consumers were more interested in getting the problem which caused the supply interruption fixed than receiving compensation for an interruption (Speers et al. 2002). As long as the number of interruptions were small and the duration of interruptions short, consumers thought they could generally cope.

A similar study by Joshi et al (2002) conducted in India with water consumers who experienced relatively frequent supply interruptions also showed an ability to cope, with consumers developing routines for dealing with intermittent supplies and adapting through storage of water. The regularity and duration of supply interruptions influences the total amount of water consumed by consumers when the intermittent supply is insufficient for allowing consumers to fully meet their water demands. However, intermittent water supply has little impact on consumption levels where most water demands are met during supply periods (Andey \& Kelkar 2009). 
Although the provision of information on water supply service quality is widely supported by consumer groups, and indeed in some jurisdictions water utilities are required to report on drinking water quality to their customers (Johnson 2003), there is little clarity about what information consumers actually want. Most water suppliers monitor various performance indicators (for example, see Coulibaly and Rodriguez (2004) or Marques and Monteiro (2001)) but there is little research examining what such information means to consumers. A study by Johnson (2003) found that overall assessments of water supply quality or supplier performance did not change as a result of receiving different types of water quality reports, with prior general beliefs about risk being more significant than the content or format of water quality reports in influencing concern about water quality.

The literature suggests that consumer priorities for water services are firstly and overwhelmingly to maximise water quality, secondly to provide an sufficient quantity of water and ensure continuity of supply, and thirdly, to ensure adequate information provision. We hypothesise, however, that water quality may be a lower consumer priority than water quantity where people are already accustomed to drinking bottled or filtered water, even if tap water fails to meet quality (and taste) expectations sufficiently for people to want to drink it. Thus, the hierarchy of consumer priorities suggested by the literature may need to be reconsidered where there are readily available drinking water sources, such as bottled water, to substitute for tap water that does not mean quality or taste expectations of consumers.

\section{Case studies of consumer preferences for water supply services}

During 2007 interviews with stakeholders in the water industry which focused on consumer issues in the water sector were conducted in Cyprus and Latvia. ${ }^{5}$ These interviews were followed in 2008 with a series of focus groups conducted with water consumers in each case study location.

Interviews were conducted with water utilities, regulators, consumer organisations, and non-government organisations ${ }^{6}$, with six to nine interviews being conducted in each case study location. A generic interview protocol was devised in order to identify interviewees' understandings of consumer related water industry issues and industry engagement with consumers, and thus approximately 30 generic questions were asked in each interview. In Cyprus the interviews were conducted in English while in Latvia the

\footnotetext{
${ }^{5}$ These interviews were part of a series of case studies in several different countries conducted as part of Work Area 6 of the TECHNEAU project. They focused on consumer related issues in the water sector, with the case study locations being chosen due to their differences in management structures, water resource challenges, and consumer behaviour.

${ }^{6}$ Referred to as Water Supplier [WS]; Regulator [R]; Consumer Organisation [CO]; and Non-Government Organisation [NGO] in excerpts.
} 
interviews were conducted in Latvian or Russian. (Although the national language is Latvian, Russian, which was widely spoken during the Soviet era is also still in widespread use.) The interviews were digitally recorded and later transcribed, and for the Latvian and Russian interviews, also translated into English. Table 1 gives a list of the organisations and numbers of people interviewed.

Table 1: List of stakeholder interviews conducted in Latvia and Cyprus.

\begin{tabular}{|l|l|l|l|}
\hline Study site & Type of organisation & $\begin{array}{l}\text { Number of } \\
\text { Interviewees }\end{array}$ & Organisation \\
\hline Cyprus & Water supplier & 2 & Water Board of Nicosia \\
\hline Cyprus & Water supplier & 1 & Water Board of Limassol \\
\hline Cyprus & Regulator / supplier & 2 & Water Development Department \\
\hline Cyprus & NGO & 1 & Cyprus Consumer Association \\
\hline Cyprus & NGO & 1 & UNDP - Action for Cooperation and Trust \\
\hline Latvia & Water Supplier & 1 & Riga Water Company \\
\hline Latvia & Consumer Organisation & 1 & Latvian Association of Water and Gas Consumers \\
\hline Latvia & NGO & 1 & Baltijas Vides Forums \\
\hline Latvia & Regulator & 1 & Riga City Public Utility Regulator \\
\hline Latvia & Regulator & 1 & Public Health Agency, Ministry of Health \\
\hline Latvia & Regulator & 1 & Department of Investment, Ministry of Environment \\
\hline
\end{tabular}

Focus groups were conducted in each case study location, with each focus group consisting of seven or eight participants of either gender and of a range of ages. ${ }^{7}$ All focus groups were conducted in the participants' native language, and were digitally recorded and later transcribed and translated into English. The criteria used for selecting participants was slightly different in the two case studies in order to reflect differences in the case studies - in the case of Cyprus with is water scarcity problems which consumers partially compensate for by the use of storage tanks, household size was thought to be a critical factor when considering group composition since large households were more likely than small households to run out of water during supply interruptions. In the case of Latvia, whether participants lived on the east or west bank of the Daugava River was thought to be a relevant factor when considering group composition as water quality is thought by some water consumers and stakeholders to vary geographical region of the city. See Tables 2 and 3 for details of the focus groups.

Table 2: List of focus groups conducted in Cyprus.

\begin{tabular}{|l|l|l|l|l|l|}
\hline & Language & Age & Household size & Residential area & Date of focus group \\
\hline Group 1 & Greek & $25-44$ years & 1 or 2 members & Nicosia & $14 / 15$ April 2008 \\
\hline Group 2 & Greek & $25-44$ years & 3 or more members & Nicosia & $14 / 15$ April 2008 \\
\hline Group 3 & Greek & $45-65$ years & 1 or 2 members & Nicosia & $14 / 15$ April 2008 \\
\hline Group 4 & Greek & $45-65$ years & 3 or more members & Nicosia & $14 / 15$ April 2008 \\
\hline
\end{tabular}

Table 3: List of focus groups conducted in Latvia.

\begin{tabular}{|l|c|c|c|c|}
\hline & Language & Age & Residential area & Date of focus group \\
\hline Group 1 & Latvian & 25-60 years & West of Daugava River, Riga & 9 April 2008 \\
\hline Group 2 & Russian & 25-60 years & West of Daugava River, Riga & 9 April 2008 \\
\hline Group 3 & Latvian & 25-60 years & East of Daugava River, Riga & 10 April 2008 \\
\hline Group 4 & Russian & 25-60 years & East of Daugava River, Riga & 10 April 2008 \\
\hline
\end{tabular}

\footnotetext{
${ }^{7}$ Referred to by participant and group number, such as [P2 Group2], in excerpts.
} 
While the primary focus of the analysis that follows will be the interviews and focus groups which were carried out in a comparable format in Cyprus and Latvia, reference will be made to the survey which was also carried out in Cyprus as a follow-on from the interviews and focus groups. In April 2009 a stratified random sample survey was carried out of 800 water consumers across Cyprus, of whom 230 were drawn from Nicosia urban area. The survey was conducted via face-to-face interviews and consisted of a mixture of open and closed questions. Adults were selected randomly in each household, with the method of the most recent birthday used to select the actual survey respondent. These survey results will be referred to where they provide quantitative data to back up the findings from the qualitative interview and focus group results. No similar survey was carried in Latvia, in part because it was found to provide less insight into the issues being investigated than the more qualitative data provided by the survey and focused groups.

\section{Consumers under quantitative water resources stress: Cyprus}

Cyprus is the largest island of the eastern Mediterranean, with an area of $9250 \mathrm{sq} \mathrm{km}$ (Food and Agriculture Organization 2007), with the internationally recognised Republic of Cyprus controlling approximately two-thirds of the island and most of the remaining third controlled by the Turkish Republic of North Cyprus, recognised only by Turkey. Per capita GDP in the Republic of Cyprus is 93 percent of the EU average (Eurostat 2008). In 2008, per capita GDP in Cyprus was $\$ 31,551$ (United Nations Statistics Division 2009).

With its Mediterranean climate of hot dry summers and, in recent years, below average rainfall, the country has faced increasing water scarcity as demand has exceeded available supply. During the summer of 2008 dam levels in Cyprus reached their lowest level in more than 20 years of just 10 million cubic metres (MCM) compared to an average end of summer level of 86 MCM (Water Development Department 2009). This scarcity has directly impacted upon domestic water supply services such that during the time that the consumer focus groups were carried out (April, 2008), Cypriot households were being supplied with water only on three days per week. Perhaps because of this direct impact on domestic water consumers, Cypriots are far more likely to say they feel well (or very well) informed about the various water-related problems facing their country $-78 \%$ compared to an EU average of just 43\% (Gallup Organisation 2009).

\section{Water quality in Cyprus}

Amongst the water industry stakeholders interviewed, water quality was seen as an important issue but of secondary importance compared to the issue of quantity. As one water supplier interviewed stated

Our challenge is to provide a sufficient quantity of water in order to meet requirements. And secondly [water of] good quality. [WS3] 
Similarly, a regulator when interviewed thought that the key issue was quantity rather than quality, stating

all the phone calls we get, most of the time have to do about not having enough water. I think that the people in Cyprus are fairly happy or confident that we get good quality water. [R2]

However, although the quantity of supply was seen as the key water issue facing Cyprus, quality was still seen as the primary priority of consumers, as described by one of the water suppliers interviewed:

Quality is number one as far as I can see on the customer's agenda and it is their prime priority...... Then once we have satisfied the quality then comes quantity. [WS1]

In the consumer focus groups, perceptions of water quality were mixed. Some consumers indicated that they thought the water was safe with comments such as:

I am satisfied and I use it. We drink it and cook with it. [P7 Group 1]

From a micro-biological point of view, the water we consume that comes from the Water Board is suitable. [P3 Group 1]

The reservoirs in each village or here at the central ones, they put chloride in and then they pipe it out. And they check it before it leaves. If there is something wrong they are not going to send it. [P8 Group 4]

Other focus group participants viewed water quality more negatively. Here, participants' judgments of water quality focused on aesthetic issues of water clarity, odour and taste when assessing the quality of their tap water, in characterising whether it was 'good' or 'bad'. The 'ideal' water quality was described as being transparent, odourless and low in salt content. Only a small minority of focus group participants stated that they drank tap water straight from the tap, with a majority preferring bottled water. (This finding was confirmed by the later consumer survey which showed that only 29.8 percent of people in Cyprus, and 17.8 percent in Nicosia, drink the water straight from the tap without filtering or boiling.) In terms of the reasons why they prefer not to drink tap water, most participants stated that they disliked the taste of tap water.

I find that the taste of the one I buy is better. Whenever I have tried to drink tap water, I can't drink it. I don't like it at all. [P6 Group 4]

Basically because it smells of chlorine. You make a cup of coffee and it smells of chlorine. [P6 Group 2]

Few participants suggested that it was their lack of confidence in the safety of the water rather than taste that was the reason for not drinking tap water, with there being a general understanding that chlorine was necessary to ensure that micro-organisms did not pose a threat to health. For example in Group 1, the following exchange of opinions occurred:

I think chlorine is needed. [P5 Group 1] 
They have to add chlorine to it. [P7 Group 1]

Yes, but it shouldn't smell bad. [P8 Group 1]

Although participants had a sense of confidence in authorities to monitor and check tap water, the aesthetic nature of tap water led for some participants to a sense of distrust.

I believe that it is checked. But still, when you will drink this water there is still that smell. It is that thing, I believe, that makes you feel insecure about the quality. [P3 Group 4]

Only a small minority of participants stated that they would be willing to pay for better quality drinking water services, even though a majority of participants indicated that they were buying bottled water.

These water quality perceptions from the focus groups were backed up by the later consumer survey. 26.5 percent of people in Cyprus and 29.3 percent in Nicosia said that they were unsure about the safety of the tap water as their initial response to the question of why they drink bottled or filtered water at home but 44.5 percent in Cyprus and 38 in Nicosia said either that the taste of the tap water or the better quality of bottled or filtered water as the reason why they drank bottled or filtered water at home. When asked whether the water supply authorities had built a safe system to ensure that there are no negative health effects for the public from the water on a scale of 0 to 10 where 0 was strongly disagree and 10 was strongly agree, 87 percent in Cyprus and 84.1 percent in Nicosia responded with 5 or higher, reinforcing the findings from the focus groups that there was not a general feeling of mistrust and that only a minority of people genuinely mistrusted the tap water supply.

\section{Water quantity in Cyprus/supply interruptions}

From the perspective of the water industry stakeholders, the major challenge facing the sector in Cyprus is the supply of a sufficient quantity of water.

I think in Cyprus because we have this problem with water shortage, I think the consumer is concerned about having enough water. That is the main problem we have and even our clients which are the intermediates between us and the people, they are worried about having enough water to give to the people. [R2]

The big problem is if we have water to supply to them. It is our major problem. [WS2]

The problem was also recognised by the water consumers in the focus groups, with comments such as:

It is our primary national problem. [P4 Group 4]

Focus group participants expressed that they were troubled by the water shortage situation and that it had affected their day-to-day lives significantly. The impact was not expressed as one of access to water for drinking consumption, but rather one of hygiene and normal household operation. People's routines and daily lives had been influenced to a large extent by the lack of water supply. 
I ran out of water today and the house came to a standstill. You can't shower...[P4 Group3]

You can't go to the toilet...[P5 Group3]

Yes, you can't go to the toilet, you can't even cook or do the dishes. [P4 Group 3]

Now we have a problem. Water regulates your way of life. [P5 Group 1]

It limits your freedom and your activities. You have to prioritise and base your schedule of housework according to when the supply is on and then wait for it to come on. [P3 Group 2]

Only a small minority, primarily older participants from small households, thought they had not been significantly affected by the lack of regular water supply.

I haven't done anything. I haven't even realised that the supply is being turned off. The two ton tank I have on the roof is enough. The only thing is that we store up on potable water. [P4 Group 1]

This concern about the water shortages expressed in the focus groups was strongly picked up in the survey where 99.9 percent of participants in Cyprus and 100 percent in Nicosia on a scale of 0 to 10 where 0 was strongly disagree and 10 was strongly agree, gave a response of 5 or more to the question of "how important is the issue of water shortage in Cyprus for you personally?".

For the participants of the focus groups, the water restrictions were inherently linked with uncertainty. One of the key areas of concern revolved around when they would receive water e.g. the specific day and hours of the day. Although in most cases the Water Board had communicated some information about what days/hours water would be supplied, this commitment was not always met in practice. Uncertainties about water provision were largely based upon the geographical location in which participants resided, or their type of accommodation. Participants likened access to water to a lottery, depending on these conditions. For example, they described how households further away from reservoirs experienced serious delays in supply, up to six hours after the supply had been turned on. Also, those residing in apartment complexes with storage tanks on the roof or in houses at relatively higher altitudes also reported that the water reaching their houses was at such a low pressure that their water tanks did not fill up.

By the time the tank of the first house fills up, and then the second, until your turn in the line comes it takes too long. This means that you may be lucky and your house is close to the beginning of the line and your tank will fill up. If you are in the middle of nowhere, however, by the time the water makes it there the supply is turned off. [P4 Group 4]

Participants in the sessions made reference to issues of equity, especially since authorities had publicly announced that all consumers would be treated equally.

[we expect] fair treatment of all households provided with water. The distribution should be equal. [P6 Group 2] 
How do we know how well they are managing it? They speak of equal distribution. How do we, me, you and the others here, know how they distribute the quantity? They said in the news that everyone would be treated equally. [P4 Group 4]

There was some scepticism expressed about equity, both between different sectors and different domestic users.

The distribution of water is unequal. There are sectors which may receive water up to $100 \%$, but they step over me who I am a household consumer because I am the only one that they can control. [P3 Group 2]

The English people in Pafos, they have their swimming pools, their golf courses and are having a good time, while Cypriot people are suffering. [P7 Group 3]

The majority of the focus group participants thought that the government was mismanaging the situation, with a common view being that the water shortages they were experiencing were caused by mismanagement.

They should have foreseen this. After all, we have always had this problem. Cyprus is always suffering from poor rainfall. This is not a problem that has appeared today. [P6 Group 4]

I am also starting to believe that there was no foresight. We know, in our entire life we have always known that we have problems with water. It doesn't rain. They should have planned for long term solutions. [P7 Group 2]

Before the cut offs, I believed that they were managing it well. But to get to the point we are now, it appears that they were not managing it well even before then. [P5 Group 1]

Why did they begin the cut offs right after the elections and not from before? In Cyprus, a little or a lot, all the parties have their share in this. [P8 Group 4]

I think that each government spent more time trying to shift the responsibility to the previous government instead of doing something. [P7 Group 4]

They could have managed it better, instead of watering the lawns of town halls and golf courses and if they had saved water we wouldn't have the problem we have now. [P4 Group 2]

Water allocations for tourism and industry were also raised as causes of the water shortages:

the hotels are given water continuously. [P4 Group 4]

We have a lot of tourism. When tourists come here they shower 4-5 times a day. [P3 Group 1]

The agriculture thing...What they are choosing to grow is inappropriate. You help out the farmer to grow something, but the wastage of water is bad for the country. [P3 Group 1]

My friend, I believe that their primary concern should be that the people have water to drink. They are inexcusable to cut the supply off. They should check how much they give to 
agriculture and cut their water off. They should give it to us so that we have water for drinking and cut off what they give to agriculture. [P5 Group 1]

Desalination was raised in all focus groups as a means of dealing with the water scarcity problems.

We have always had this issue with water in Cyprus. I remember in the past as well when droughts would last for three, four, five years. The desalination is needed. But each government should keep it in mind that there needs to be conservation. The desalination is a backup in case of emergency. [P7 Group 1]

In the long run, I do not see desalination as the only solution. They should save up on the water they have. Figure out where the water from the projects, the dams they made has gone to and if more dams are needed then to do them so that we would be satisfied with what we have. They should manage correctly what we have. [P5 Group 1]

In addition to desalination, fixing the current infrastructure was also seen as being important, particularly in terms of reducing leaking from the reservoirs and distribution system.

\section{Information needs in Cyprus}

The dominant model of consumer engagement in Cyprus is one-way interaction. When stakeholders were asked about the communication channels they had in place for communicating with consumers, responses were orientated around the idea that consumers could telephone the organization if they needed to.

We inform them about how to contact the water board in the newspapers. There are telephone numbers. Each person, each citizen, can easily find the telephone number according to the town they are living in they can contact their water board. [WS3]

It was noted by some suppliers that in cultural terms it is not in the nature of Cypriots to complain, with most existing forms of communication therefore consisting of information bulletins provided with bills.

Through the bills we try to inform them about the water scarcity in order to avoid the water waste. [WS3]

The water regulator discussed how they were in the initial stages of developing information campaigns, particular on water conservation but was unsure how effective such measures would be:

I want to see how efficient this thing is but we have not yet set down something that can give us a measure. I do not think that we can see a significant reduction of water like use at the domestic part.... But I think [we will develop] some questionnaires and set up some meetings to see whether this is possible. I will also try to see how other people did it. And I will try to get some guidelines and directions on how to measure the effect of the campaign. [R1]

One water supplier thought that there was not enough dialogue on water shortages nor enough strategies in place to inform people about the subject: 
There are no sorts of open channels of communication between our organization and the customer apart from leaflets you know which we send with the bills from time to time informing them of either that we have sort of shortage of water and that they should conserve water or that you know that there is a need to increase the cost of water. [WS1]

The majority of focus group participants indicated a strong demand for actions from the water suppliers that would inform them about, and promote water conservation measures and of building a water conservation culture amongst the population. In the context of water conservation in particular, the level of information passed on to consumers was considered to be minimal and insufficient. Participants expressed a desire for information about water conservation measures that could be applied in the home.

They could have sent some advertising material from time to time on their own, not in bills. I think that all of us, when we open the envelope with the bill, you are going to throw away the advertising leaflet and you are going to keep only the bill. Only if they send it on its own you are going to open the envelope and say 'what is this?' [P3 Group 3]

Besides the mass media, there are no information campaigns. That is my perception. In the past they used to do more often. [P7 Group 2]

Very few participants thought that they were being given enough information, with most participants expressing the desire for more information from the water supplier and more extensive education campaigns to encourage people to save water. Some participants also expressed a desire for more transparent and open decision making for dealing with the water supply problems:

meetings should not be behind closed doors. People are left in the dark and nobody knows why some decisions are taken. Some things should be heard. [P3 Group 4]

At least some things should be out in the open. Hear the proposals and why they are rejected. [P7 Group 4]

\section{Consumers in a system undergoing change: Riga, Latvia}

Located in north-eastern Europe on the eastern coast of the Baltic sea, with land borders with Estonia, Russia, Byelorussia, and Lithuania, Latvia has a total area of $64,590 \mathrm{~km}^{2}$ and a population of 2.3 million (Food and Agriculture Organization 2007). While the official language is Latvian, the Russian speaking minority makes up approximately onethird of the population. Latvia has a humid continental climate with mild summers and cold winters.

The capital city Riga is the largest city, with a population of 717,371 (Central Statistical Bureau of Latvia 2009). The population has steadily declined from a peak of around 900,000 in 1990, as has the population of Latvia as a whole. Per capita GDP in Latvia is approximately half the EU average (Eurostat 2008), being \$14,956 per year (United Nations Statistics Division 2009). 
The water resources of Latvia are abundant, greatly exceeding current and expected future demands (Latvian Environment Geology and Meteorology Agency 2002). Perhaps due to the relatively plentiful availability of water resources in Latvia, only 27 percent of Latvians say they feel well (or very well) informed about the water resource problems facing their country (Gallup Organisation 2009). Drinking water in Riga is supplied by Rīgas Ūdens (Riga Water), a company wholly owned by the municipality of Riga. The water supply system draws upon two sources of water, the Daugava River and groundwater, with approximately half coming from each of these sources. There is a predominantly cast iron pipe distribution network which suffers from corrosion problems, leading to leakages and increasing water turbidity (Juhna \& Klavinš 2001).

\section{Water quality in Riga}

While the quality of the drinking water supply in Riga has improved in recent years, water quality is still seen as the key consumer issue. Water regulators when questioned about the key consumer issues stated, for example:

The quality of water, I believe, is the most important thing. To receive the service in the appropriate quality. [R3]

They are interested only in two questions, that's for sure - the quality of the service and the rates, because these things influence them directly. [R2]

Similarly, one of the NGO representatives commented:

in my opinion, [consumers] are mostly interested in the quality of the product. Do water providers have problems too? Well, that's another question. They look at this problem in general and they are interested in the technical things, the quality of the water pipes, the quality of the dirty water and so on but the consumer is mostly, in my opinion, interested in the quality of the final product or how he sees the quality. [NGO1]

Both regulators and water service providers raised the concern that although the water quality of the system was good, the pipe system potentially created water quality problems for the consumer. As one of the water suppliers commented:

I don't think it is quality but it could be quality, but in most of the cases it's not the bad quality of Riga's water but the bad quality of the pipes [WS1]

Similarly, one of the NGOs interviewed commented:

it is possible that in some places there is this technical problem connected with bad pipes, consequently the quality is not so high. [NGO1]

the main problem could be the mistrust in the quality of water and the quality of water pipes. This problem is actual not only in Riga but in all Latvia. Of course there are different indicators but the most widespread is the heightened concentration of iron ion and it can be clearly seen if the water is yellow and dirty. People don't like that. [NGO1]

Comments in the focus groups supported the views expressed by industry stakeholders that water quality was seen by consumers from across the city as a prominent issue. For 
all, assessments of tap water quality involved considerations about taste, colour, and clarity (turbidity).

Sometimes at first the water is absolutely black... It is so disgusting. [P4 Group 1]

The quality could be better, really. [P7 Group 1]

However, not all consumers thought the water they received was of poor quality, and some of the focus group participants indicated that they recognised that the quality of water received by consumers could vary depending upon their location in the city and the quality of the local pipe network:

I live in the centre and I think that we have better water if compared to those living in Pardaugava. [P6 Group 1]

In the past, I used to live in the centre, on Matisa Street, water was horrible. It was impossible to drink it. Now I live in Pardaugava - water is very good. [P1 Group 3]

I think, we may talk about not only regions. Two houses near each other may differ - one with replaced sewer-pipes, the other - not replaced, of course. [P2 Group 3]

Industry stakeholders thought that consumer concern about tap water quality was leading to risk averting behaviour, such as the drinking of bottled water or filtered water.

If they don't believe in the quality of water and think that the pipes are bad, they somehow filter this water or use mineral water. These are the consequences. [NGO1]

Keeping in mind those worries about the quality of tap-water I would say that they do not trust us 100 percent. There could be less worries about the usage of tap-water and this Soviet myth about boiling water. [R1]

Similarly, the consumer association representative when interviewed also thought that the drinking of bottled water was indicative of mistrust in the quality of the tap water:

This is an indication that consumers do not have trust in tap water quality. There is an opinion that our water supply system cannot provide a good water quality. In some areas that is really the case. [CO1]

This view of there being a lack of trust in the tap water by some consumers was supported by the discussion in the focus groups.

I don't drink unboiled water... [P7 Group 1]

Well, in general yes. We buy filters, such special filters which are installed on the tap and there are also special appliances which... But in general, now we more often buy water in bottles, so it is, especially drinking water. [P9 Group 2]

When asked the reasons why they drank boiled or bottled water, people commented things like: 
It makes us feel safer. [P2 Group 1]

However, a lack of trust was also expressed in bottled water by some focus group participants:

I have heard that somewhere in the city they simply take tap water to fill bottles. [P5 Group 1]

I don't trust bottled water. We don't know its origin. I think that bottled water could be the same as tap water. [P6 Group 3]

When asked what aspects of their service provision they would be willing to pay more for, the overwhelming response in the focus groups was better water quality. However, participants thought that they should not have to pay so much for poor quality water, with comments like:

Quality isn't very good, and therefore the price could be lower. [P3 Group 4]

Prices have been raised, but the quality is not adequate, just the same as it was. [P2 Group 1]

However, as a public service, system renewal or improvements ultimately will obviously have to be met by the water consumer, as recognised by industry stakeholders:

Of course, the consumer will be influenced by the rates because all the investments reflect in the rates.... But those living in the developed cities have to understand that any improvements will cost them some money. Then we can start talking about saving or some other things. But the most important is the fact that we cannot get any improvements with any financing. As this is a public service then the people have to pay for that. [R2]

....every consumer wants these payments to be lower but we have to keep in mind the fact that the delivery of all services requires some capital and expense. [NGO1]

\section{Water quantity in Riga}

Latvia is a country richly endowed with water, having $7313 \mathrm{~m}^{3}$ of renewable water resources per capita (compared to Cyprus' $922 \mathrm{~m}^{3}$ ) (Food and Agriculture Organization 2009). This lack of water scarcity on a national scale means that there are no water supply issues due to a lack of water availability. However, it was still recognised by some of the stakeholders interviewed that the consumers are concerned about water quantity issues, even if it not their current main concern:

They want water to be cheap, in good quality and of course, they are interested in non-stop delivery. [NGO1]

Amongst focus groups participants it was generally recognised that continuity of supply was good. 
We have no problems with it - we have water regularly. [P3 Group 2]

Where focus group participants did refer to recent supply interruptions they related to repairs and pipe replacement activities:

last year I was forced to live without water for a month because they were replacing pipes. We were buying water in a shop. But we didn't have water for washing. We brought clothes to our parents in order to wash them. [P3 Group 3]

Recently, repairs are made often. During repairs, water-supply is turned off, and when it's turned on again... after repairs water is available. Before, it wasn't always like that. The more repairs the better availability of water. [P4 Group 4]

The issue of water pressure was raised by one water supplier, who suggested that it was no longer a problem:

In Riga there are no pressure problems anymore, the pressure of water is satisfactory and even more. In some houses there could be some pressure problems but that is only inside the house and it is the problem of pipes..... Some time ago the main problem was the pressure, then the second problem was the quality. [WS1]

However, some focus group participants did see water pressure as an ongoing problem:

I would say pressure, sometimes it is very low.... I don't talk about the upper floors. I'm on the first floor, and sometimes at evenings pressure is very, very low. [P8 Group 1]

In winters when there's no pressure, they freeze... Water cannot get to the upper floors... [P2 Group 3]

\section{Information needs in Riga}

One of the water regulators interviewed thought that some of the consumer concerns with water quality were linked to poor information provision on behalf of the water provider:

If the consumer is not sure about the quality, of course he will have worries. Some time ago there was this myth that you had to boil water before the consumption. There were problems with chlorine and it smelled bad as well. Nowadays we do not have this problem anymore because we have different methods how to work with water. Yes, rather often these worries are from not knowing the right information. [R1]

However, the water supplier interviewed acknowledged that they did not have a strategy in place for liaising with consumers:

If I understand it correctly we do not have a marketing policy at the moment, we lack a marketing strategy, how to inform our clients. Each year we send out booklets but I don't think that people are interested in the amount of water consumed or in different chemical substances but we are planning direct contact with this client service, and recognised its importance. [WS1] 
I consider it to be one of our primary concerns because without it there can be no natural monopoly..... In this situation communication with our clients is of paramount importance. [WS1]

One of the regulators thought that consumers were not provided with sufficient information:

I believe that the consumer is not informed well enough on the quality of water..... I believe that you (as a consumer) are also not sure about the quality of drinking water. I think there should be much more information from the providers. [R1]

In the focus group sessions the lack of dialogue between consumers and the water company was evident, with participants stating that they did not receive information or even water bills from the water company as these were sent to their apartment's house management. Participants also expressed that they felt they had no 'voice' as consumers. When asked if they had ever been in contact with the water company people commented things like:

How can I be in touch if I even don't know who they are? [P8 Group 3]

Bills are sent by house management. [P2 Group 3]

No information, nothing...[P8 Group 3]

Participants stated that they were unsure about how to make contact with the water supplier and thought they would need to go through their apartment's house management.

I think we must firstly turn to house management, not to Rīgas ūdens. [P8 Group 2]

Firstly, you turn to house management..... Will it be better if you turn to Rīgas ūdens? [P5 Group 3]

Many participants expressed the feeling that they were disenfranchised due to having house management act as their intermediary.

But house management doesn't function well as a mediator: it has undertaken to act as a mediator between us and Rīgas ūdens, we pay them, but we cannot influence the pace. We're used to it, and we don't expect anything better. [P7 Group 4]

Similarly, it was thought that the water company would use house managers as an intermediary when trying to contact consumers. Focus group participants also expressed the desire to receive more information from the water company. In particular, people were interested in receiving information relating to water quality:

About tests of quality or at least, information about their activity. That information is interesting to me. [P5 Group 2]

They could simply provide more information on water content, what it contains and in what amounts. [P6 Group 3] 
At least we should be able to enter their website and see what our water consists of. We are living in the era of information technologies. We should be able to read their information. I have visited the website but there is no such thing as the results of analysis. None of them has. [P6 Group 1]

Requests for information about water quality were synonymous with the need for assurance. Participants were aware that water quality tests were already an existing mandatory requirement, but that information was not available in the public domain in Riga. It was suggested that accessibility to such information, and the knowledge that their water complies with minimum legislative standards, would lead to fewer concerns.

\section{Discussion and conclusions}

Despite the very different nature of water supply problems facing Cyprus and Riga, consumer preferences for water supply services in the two regions were broadly speaking similar in that they related to maximising the quality and quantity of the water received, and the provision of information broadly speaking also related to water quality and quantity. However, unsurprisingly there were some differences in priorities despite the water literature suggesting that the number one priority for water consumers is overwhelmingly water quality. Much of this water literature was developed in relation to countries where continuous water supply for all consumers is taken for granted, and there is still scope to improve water quality.

While water quality was undoubtedly the one priority for water consumers in Riga, it is less clear whether this was the case in Cyprus. Only a small minority of focus group participants in Cyprus said they drank tap water straight from the tap, thus suggesting that the tap water is falling short of the water quality expectations of consumers, at least in terms of taste (but not necessarily in terms of safety). However, the focus groups discussions and some of the water industry stakeholder interviews suggested that water quantity and improving the reliability of supply was a higher priority for consumers. Few participants in the focus groups said they would be willing to pay more for better quality drinking water services but participants clearly indicated they wanted a more reliable service, even if that meant the use of desalination.

This emphasis on quantity rather than quantity problems in Cyprus would appear to be rational in that most water use is for functions that do not require high quality drinking water but just water of adequate quality for activities such as toilet flushing and washing. Small quantities of high quality water for drinking can be easily and reasonably cheaply obtained by purchasing bottled water with little impact on quality of life or daily routines. However, loss of bulk water supply to a house, even for just a short period of time, can quickly impact on daily functions and lifestyle. Thus for water quality problems (in more developed countries at least) there are affordable and readily available solutions for consumers but for water quantity problems, options for consumers are more limited and likely to have a much more significant effect on lifestyle.

Despite the literature (such as Bates (2000), UK Drinking Water Inspectorate (1998), and Consumer Council for Water (2005)) suggesting that consumers prioritise the safety and 
quality of their water supply over quantity and continuity of service, it would appear that the hierarchy of needs and the preferences of consumers may be slightly different. Assuming that safe drinking water (the key priority of consumers) is readily available and affordable in the form of bottled water, the case studies examined in this study suggest that consumers prioritise quantity and continuity of supply over tap water quality. However, consumer attitudes must always be considered in context and thus the recent problems faced by consumers will influence what they see as a priority for their water supplier.

When supply is unreliable, reliability takes precedence, once water supply is reliable, quality issues come to the fore as the priority of water consumers.

\section{Acknowledgements}

This research was carried out as part of Work Area 6 of the TECHNEAU project, an integrated project funded under FP6 of the European Commission, grant number:

018320.

\section{References:}

Aini, M., Fakhru'l-Razi, A., \& Suan, K. (2001). Water crisis management: Satisfaction level, effect and coping of the consumers. Water Resources Management, 15:31-39.

Al-Ghuraiza, Y., \& Enshassib, A. (2006). Customers' satisfaction with water supply service in the Gaza Strip. Building and Environment, 41:1243-1250.

Andey, S., \& Kelkar, P. (2009). Influence of intermittent and continuous modes of water supply ono domestic water consumption. Water Resources Management, 23: 25552566.

Bates, A. J. (2000). Water as Consumed and its impact on the consumer - do we understand the variables? Food and Chemical Toxicology, 38:S29-S36.

Burn, L. S., Tucker, S. N., Rahilly, M., Davis, P., Jarrett, R., \& Po, M. (2003). Asset planning of water reticulation systems - the PARMS model. Water Science and Technology, 31:55-62.

Central Statistical Bureau of Latvia (2009). 4-5. Resident population by region, city and district at the beginning of the year. Riga: Central Statistical Bureau of Latvia,. http://data.csb.gov.lv/Dialog/varval.asp?ma=04-05a\&ti=45.+RESIDENT+POPULATION+BY+REGION\%2C+CITY+AND+DISTRICT+AT + THE+BEGINNING+OF+THE+YEAR\&path=../DATABASEEN/Iedzsoc/Annual\% 20statistical\%20data/04.\%20Population/\&lang=1

Coulibaly, H., \& Rodriguez, M. (2004). Development of performance indicators for small Quebec drinking water utilities. Journal of Environmental Management, 73:243-255.

Department for Environment Food and Rural Affairs (2002). Survey of public attitudes to quality of life and to the environment. London: Department for Environment Food 
and Rural Affairs.

http://www.defra.gov.uk/environment/statistics/pubatt/download/survey2001.pdf

Eurobarometer (2005). Services of General Interest. Brussels: European Commission. http://ec.europa.eu/public_opinion/archives/ebs/ebs_219_report_en.pdf

European Commission Health and Consumer Protection Directorate General (2000). First

Report On The Harmonisation Of Risk Assessment Procedures. European

Commission Health and Consumer Protection Directorate General. http://ec.europa.eu/food/fs/sc/ssc/out82_en.html

Eurostat (2008). Europe in figures: Eurostat yearbook 2008. Eurostat. http://epp.eurostat.ec.europa.eu/cache/ITY_OFFPUB/KS-CD-07-001/EN/KS-CD07-001-EN.PDF

Falahee, M., \& MacRae, A. W. (1995). Consumer appraisal of drinking water: Multidimensional scaling analysis. Food Quality and Preference, 6:327-332.

Food and Agriculture Organization (2007). Aquastat: FAO's Information System on Water and Agriculture. Land and Water Development Division, Food and Agriculture Organization. http://www.fao.org/ag/agl/aglw/aquastat/main/index.stm

Food and Agriculture Organization (2009). Aquastat: FAO's Information System on Water and Agriculture. Land and Water Development Division, Food and Agriculture Organization. http://www.fao.org/nr/water/aquastat/data/query/index.html

Gallup Organisation (2009). Flash Eurobarometer on water. Flash EB Series \#261. Brussels: European Commission.

Hrudey, S., Hrudey, E., \& Pollard, S. (2006). Risk management for assuring safe drinking water. Environment International, 32:948-957.

Institut Français de l'Environnement (2000). La préoccupation des Français pour la qualité de l'eau. Les données de l'environnement, 57:1-4.

Johnson, B. (2003). Do Reports on DrinkingWater Quality Affect Customers' Concerns? Experiments in Report Content. Risk Analysis, 23:985-998.

Joshi, M., Talkhande, A., Andey, S., \& Kelkar, P. (2002). Urban community perception towards intermittent water supply system. Indian Journal of Environmental Health, 44:118-123.

Juhna, T., \& Klavinš, M. (2001). Water-Quality Changes in Latvia and Riga 1980-2000: Possibilities and Problems. Ambio, 30:306-314.

Latvian Environment Geology and Meteorology Agency (2002). Environmental Indicators in Latvia 2002. Riga: Latvian Environment, Geology and Meteorology Agency. http://www.lvgma.gov.lv/produkti/soe2002_eng/udeni/udeni.htm

Marques, R., \& Monteiro, A. (2001). Application of performance indicators in water utilities management - a case-study in Portugal. Water Science and Technology, 44:95-102.

Martijn, C., de Rooy, M., \& Piriou, E. (1998). Beleving van water: adviezen voor effectieve communicatiestrategieen bij de aanpak van diffuse bronnen gebaseerd op interviews met leken. Wageninegen: Wageninegen University and Research Centre Publications.

McGuire, M. (1995). Off-flavours as the consumer's measure of drinking water safety. Water Science and Technology, 31:1-8. 
Means, E. G., Brueck, T., Dixon, L., Manning, A., Miles, J., \& Patrick, R. (2002). Drinking water quality in the new millennium: The risk of underestaimating public perception. American Water Works Association Journal, 94:28-33.

Speers, A., Burn, S., MacDonald, D., Nancarrow, B., Syme, G., \& Young, M. (2002). Determining Customer Service Levels - Development of a Methodology:

Overarching Report. Canberra: Commonwealth Scientific Investigation and Research Organisation http://www.myoung.net.au/water/publications/Overarching_Report_20020718.pdf

Tuhovčák, L., \& Ručka, J. (2007). Hazard identification and risk analysis of water supply systems. LESAM 2007 - 2nd Leading Edge Conference on Strategic Asset

Management. Lisbon, Portugal: International Water Association. http://www.waterrisk.cz/dokumenty/lesam_2008.pdf

Turgeon, S., Rodriguez, M. J., Theriault, M., \& Levallois, P. (2004). Perception of drinking water in the Quebec City region (Canada): the influence of water quality and consumer location i nthe distribution system. Journal of Environmental Management, 70:363-373.

UK Consumer Council for Water (2005). Shaping the Consumer Council for Water Nov 2005. Birmingham: Consumer Council for Water. http://www.ccwater.org.uk/upload/pd/Shaping_the_Consumer_Council_for_Water_ Research_Report_291105.pdf

UK Drinking Water Inspectorate (1998). Consumer Consultation by DWI with relation to the 1999 Periodic Review: Summary Report on Research Findings. London: Drinking Water Inspectorate.

UK Drinking Water Inspectorate (2000). Drinking Water Quality Report of Public Perceptions in 2000. London: Drinking Water Inspectorate. http://www.dwi.gov.uk/consumer/marketr/cr2000.htm

United Nations Statistics Division (2009). Social indicators: Indicators on income and economic activity. New York: United Nations Statistics Division. http://unstats.un.org/unsd/demographic/products/socind/inc-eco.htm

Water Development Department (2009). Water storage in dams 1987-2008. Nicosia: Water Development Department. http://www.moa.gov.cy/moa/wdd/Wdd.nsf/f8ca32f24081da0ac22573e000406fff/e02 1804a25cbef47c2256e7e004c5306/\$FILE/48.pdf

World Bank (2010). Country Groups. World Bank. http://go.worldbank.org/D7SN0B8YU0

World Health Organization (2006). Guidelines for Drinking-water Quality: incorporating first addendum. Geneva: World Health Organization. 